\title{
PEMBERDAYAAN PEREMPUAN PENGRAJIN TENUN IKAT DI KAMPUNG PRAI IJING, DESA TEBAR, KECAMATAN KOTA, KABUPATEN SUMBA BARAT, NUSA TENGGARA TIMUR UNTUK MENINGKATKAN PEREKONOMIAN KELUARGA DAN MENDUKUNG PENGEMBANGAN PARIWISATA DAERAH.
}

\author{
Selfesina Samadara, ${ }^{1 *}$, Jennie S. Sir ${ }^{2}$ Pieter D. Samadara ${ }^{3}$ \\ 1,2,3 Politeknik Negeri Kupang \\ *Email : selfi_samadara@yahoo.com
}

\begin{abstract}
Abstrak
Tenun ikat tradisional merupakan salah satu sumber pendapatan yang dapat diandalkan. Proses tenun ikat banyak melibatkan kaum perempuan, sedangkan keterlibatan kaum laki-laki lebih kepada mencari bahan baku untuk campuran pada proses pewarnaan alami, selain itu untuk memenuhi kebutuhan hidup keluarga, para laki-laki juga bekerja bertani. Hasil penelitian menunjukkan budaya, adat istiadat dan pandangan hidup mempengaruhi bentuk dan wujud kain tenun, setiap suku memiliki karakter, gaya, ciri, bentuk, motif dan warna yang digunakan karena berkaitan erat dengan latar belakang geografis sejarah dan budaya. Nilai dalam motif kain tenun terus dipertahankan karena dianggap sebagai ungkapan jati diri mereka dan karya indah para leluhur. Kain tenun merupakan salah satu usaha untuk melestarikan budaya daerah dalam rangka pembinaan dan pengembangan kebudayaan nasional. Tradisi tenun ikat tradisional perlu mendapatkan perhatian dari berbagai pihak, karena tradisi ini merupakan sebuah ikon yang dapat ditonjolkan untuk Kabupaten Sumba Barat dan memiliki nilai jual hingga ke mancanegara.
\end{abstract}

Kata kunci: Pemberdayaan, Pengrajin Tenun lkat, Sumba Barat.

\section{PENDAHULUAN}

Pengerahan sumber daya ekonomi yang dimiliki rumah tangga, telah menuntut wanita sebagai istri dapat menopang ketahanan ekonomi keluarga. Kondisi demikian merupakan dorongan yang kuat bagi wanita untuk bekerja diluar rumah. Dalam beberapa tahun terakhir keterlibatan wanita pada sektor publik menunjukkan angka yang terus meningkat. Hal ini menunjukkan bahwa motivasi wanita untuk bekerja di sektor publik semakin tinggi. Dari total populasi 162 juta jumlah pekerja di Indonesia (data Badan Pusat Statistik tahun 2014), saat ini ada 63 juta pekerja wanita yang membantu pertumbuhan ekonomi Indonesia. Itu artinya, jumlah pekerja wanita hampir sama besarnya dengan pekerja laki-laki. Yang lebih penting, saat yang sama wanita juga menemukan kebebasan untuk tetap menjalankan perannya sebagai ibu.

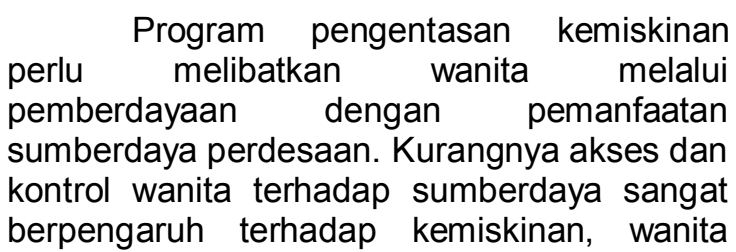

paling menderita ketika masyarakat mengalami kelangkaan sumberdaya. Sesuai dengan rekomendasi untuk pencapaian pembangunan yaitu meningkatkan peran wanita dalam proses pembangunan. Program pembangunan akan berhasil dengan meningkatkan posisi wanita dalam masyarakat sesuai salah satu pembangunan millennium dengan salah satu indikator mendorong kesetaraan gender dan pemberdayaan wanita dan menjamin kelestarian fungsi lingkungan hidup.

Upaya strategis dalam menjawab masalah kemiskinan masyarakat adalah gerakan pemberdayaan masyarakat, secara khusus untuk pembangunan di desa atau perdesaan. Pemberdayaan masyarakat akan memungkinkan terjadinya peningkatan kemampuan masyarakat dalam berperan untuk mengakses atau menjangkau sumber daya yang ada di sekitarnya. Partisipasi masyarakat hanya dapat dibangun melalui pemberdayaan, karena pemberdayaan adalah jalan menuju partisipasi (empowerment is road to participation dalam Tonny,2006). Oleh sebab itu, pembangunan perdesaan harus 
bersandar pada partisipasi masyarakat yang disesuaikan dengan potensi lokal yang ada dan dimiliki berupa komoditas yang berbasis masyarakat. Pengembangan komoditas lokal sebagai salah satu upaya meningkatkan potensi ekonomi lokal, diharapkan akan membantu terlibatnya semua masyarakat alam gerakan membantu dirinya sendiri, yakni usaha ekonomi produktif yang berbasis kerakyatan (Sumarti et al,2006). Konsep pengembangan ekonomi lokal merupakan kerjasama seluruh komponen masyarakat di suatu daerah (lokal), untuk mencapai pertumbuhan ekonomi secara berkelanjutan yang akan meningkatkan kesejahteraan ekonomi dan kualitas hidup (Syaukat dan Hendrakusumaatmaja,2006).

Penelitian ini dilakukan di Kampung Prai ljing, Desa Tebar, Kecamatan Kota, Kabupaten Sumba Barat. Di desa ini banyak dijumpai keluarga miskin telah menekuni sebagai pengrajin tenun ikat khas Sumba Barat dengan menggunakan pewarna alami dari tanaman. Menurut penenun tradisional di Kampung Prai ljing, Desa Tebar, Kecamatan Kota, bahwa telah banyak wisatawan asing yang datang untuk melihat proses tenun ikat tradisional. Wisatawan nasional maupun manca negara pernah datang untuk menyaksikan kegiatan tenun ikat tradisional, dan wisatawan tersebut lebih menyukai tenun ikat tradisional yang menggunakan pewarna alami dibandingkan dengan penggunaan pewarna tekstil seperti naptol meskipun warna kain tenun dengan pewarna alami tidak secerah kain tenun dengan pewarna tekstil, selain itu, hasil tenun ikat tersebut banyak dibeli untuk dibawa pulang oleh wisatawan asing sebagai buah tangan, ini berarti kain tenun ikat tradisional memberikan tambahan penghasilan bagi penenun.

Tenun ikat merupakan salah satu komoditas lokal yang menjadi sumber penghasilan bagi rumah tangga atau masyarakat di Kampung Prai ljing, Desa Tebar, Kecamatan Kota, Kabupaten Sumba Timur, Propinsi Nusa Tenggara Timur. Selain kerajinan tenun ikat, juga terdapat sumber lain yakni peternakan dan perkebunan sebagai mata pencarian utama masyarakat Sumba Barat, bahkan masyarakat Nusa Tenggara Timur umumnya. Kerajinan tenun ikat di Kabupaten Sumba Barat merupakan salah satu jenis industri kerajinan yang paling besar jumlahnya.

$$
\text { Penelitian ini bertujuan untuk }
$$

Pemberdayaan Perempuan Pengrajin Tenun Ikat untuk meningkatkan perekonomian keluarga dan mendukung pengembangan pariwisata daerah di Kabupaten Sumba Barat. Untuk mencapai tujuan tersebut maka akan di lakukan eksplorasi (1) tentang potensi pengembangan dan permasalahan yang dihadapi oleh perempuan pengrajin Tenun Ikat, serta kebutuhan perempuan pengrajin Tenun Ikat, (2) upaya yang telah dilakukan oleh stakeholder untuk memberdayakan perempuan pengrajin Tenun Ikat, (3) Sejauh mana proses dan hasil produksi kerajinan Tenun Ikat telah dimanfaatkan sebagai daya tarik wisata utama untuk mendukung pengembangan pariwisata daerah, 4) merumuskan model pemberdayaan perempuan pengrajin pariwisata daerah untuk meningkatkan perekonomian keluarga dan mendukung pengembangan desa wisata di Kabupaten Sumba Barat

\section{METODE PENELITIAN}

Metode yang digunakan dalam penelitian ini adalah melalui sarasehan dan seminar yang bertujuan untuk memberdayakan perempuan pengrajin tenun ikat agar dapat menjadi penggerak perekonomian masyarakat. Implementasi pemberdayaan perempuan pengrajin tenun ikat melalui penguatan sistim bapak angkat dan penguatan jaringan pemasaran online dengan pembuatan website. Pemberdayaan ini menggaris bawahi pentingnya peran pengusaha lokal yang sudah mapan dan berkembang untuk menjadi bapak angkat bagi para perempuan pengrajin tenun ikat, sehingga mereka mampu memperluas akses terhadap sumber daya produksi, akses terhadap informasi mengenai berbagai hal yang berkaitan dengan usaha tenun, akses terhadap pasar dan pemasaran tenun.

Penelitian ini merupakan penelitian deskriptif kualitatif dengan metode studi kasus tunggal. Sumber data utama diperoleh dari perempuan pengrajin tenun ikat di Kampung Prai ljing, Desa Tebar, Kecamatan Kota, Kabupaten Sumba Barat. Teknik pengambilan sampel menggunakan purposive sampling dan snowball sampling. Teknik pengumpulan data menggunakan wawancara mendalam dan observasi. Uji validitas data menggunakan triangulasi sumber. Untuk menganalisis data menggunakan analisis model interaktif yaitu dari pengumpulan data kemudian reduksi data, sajian data, terakhir penarikan kesimpulan dan verifikasi. Adapun populasi 
dalam penelitian ini adalah wanita pengrajin tenun ikat di Kampung Prai ljing, Desa Tebar, Kecamatan Kota, Kabupaten Sumba Barat berjumlah 55 orang. Data dalam penelitian ini adalah data primer, yang berupa data penduduk yang ikut dalam program pemberdayaan wanita, waktu bekerja, kegiatan sosial kemasyarakatan, pendapatan dari pengrajin dan pengelolaan lahan ladang yang dimilikinya, pendapatan seluruh keluarga, jumlah anak dan data data lainnya. Teknik analisis data yang digunakan dalam penelitian ini adalah dengan analisis deskriptif kualitatif, yaitu dengan melakukan penalaran logis. Data temuan lapangan disusun secara sistematis yang menunjukkan bagaimana peran aktif wanita dalam peningkatan ekonomi rumah tangga dengan membentuk sebuah model pemberdayaan wanita.

\section{HASIL DAN PEMBAHASAN}

Secara astronomis profil Kabupaten Sumba Barat terletak antara $9^{\circ} 22-9^{\circ} 47$ LS dan antara $119^{\circ} 08-119^{\circ} 32$, Kabupaten Sumba Barat diapit/berbatasan langsung dengan Kabupaten Sumba Tengah di bagian barat dan dibagian timur berbatasan dengan Kabupaten Sumba Barat Daya. Sedangkan dibagian selatan berbatasan langsung dengan Samudera Indonesia,dan Utara berbatasan langsung dengan Selat Sumba.Secara regional Nusa Tenggara Timur, Kabupaten Sumba Barat terletak dalam ruang daratan Pulau Sumba dengan luasan wilayah berukuran besar yang mempunyai aglomerasi hunian cukup besar atau berpotensi besar untuk mendukung hunian. Secara administrasi Kabupaten Sumba Barat terdiri dari 6 (enam) Kecamatan yang terdiri dari 74 (tujuh puluh empat) desa dan kelurahan,dan memiliki luas wilayah $737 \mathrm{Km} 2$.

Dari aspek Kependudukan, jumlah penduduk Kabupaten Sumba Barat terbesar terdapat di Kecamatan Kota Waikabubak sebanyak 31.673 jiwa, Kecamatan Loli sebanyak 29.730 jiwa dan Kecamatan Tana Righu sebanyak 19.383 jiwa, Kecamatan Lamboya sebanyak 17.393 jiwa, Kecamatan Wanokaka sebanyak 15.536 jiwa dan Kecamatan Laboya Barat sebanyak 8.037 jiwa. Dari 6 (enam) kecamatan yang ada di wilayah Kabupaten Sumba Barat, Kecamatan Kota Waikabubak yang paling banyak penduduk sekitar 31.673 jiwa dengan tingkat kepadatan 2,42 jiwa/Km2. Laju pertumbuhan penduduk Kabupaten Sumba Barat per tahun selama lima tahun terakhir rata-rata sebesar $2,34 \%$. Untuk lebih jelasnya jumlah penduduk Kabupaten Suma Barat dapat dilihat pada Tabel 1 berikut :
Tabel 1. Aspek Kependudukan

Kabupaten Sumba Barat

\begin{tabular}{|c|c|c|c|c|c|}
\hline \multirow[b]{2}{*}{ No } & \multirow[b]{2}{*}{ Kecamat-an } & \multirow{2}{*}{$\begin{array}{c}\text { Luas } \\
\text { Terba } \\
\text {-ngun } \\
\text { (Ha) }\end{array}$} & \multicolumn{2}{|c|}{ Penduduk } & \multirow[b]{2}{*}{$\begin{array}{c}\text { Keterang- } \\
\text { an }\end{array}$} \\
\hline & & & $\begin{array}{l}\text { Jumlah } \\
\text { Jiwa }\end{array}$ & $\begin{array}{l}\text { Kepadat } \\
\text {-an } \\
\text { Jiwa/Ha }\end{array}$ & \\
\hline 1 & Lamboya & 3.600 & 17.393 & 4.83 & Pedesaan \\
\hline 2 & Wanukaka & 4.500 & 15.536 & 3.45 & Pedesaan \\
\hline 3 & Laboya Barat & 6.00 & 8.037 & 13.40 & Pedesaan \\
\hline 4 & Loli & 6.300 & 29.730 & 4.72 & Pedesaan \\
\hline 5 & $\begin{array}{l}\text { Kota } \\
\text { Waikabubak }\end{array}$ & 1.310 & 31.673 & 24.18 & Perkotaan \\
\hline 6 & Tana Righu & 1.800 & 19.383 & 10.77 & Pedesaan \\
\hline & Jumlah & & 121.752 & 61.34 & \\
\hline
\end{tabular}

Sumber : Badan Pusat Statistik Kab. Sumba Barat

Gambaran Umum Tentang Kain

Tenun Sumba menunjukkan bahwa seni Tenun Ikat Sumba lahir dari kekayaan alam setempat melalui tangan-tangan seniman yang begitu mencintai warisan leluhurnya. Proses penciptaan kain tenun yang memakai pewarna alam serta pemilihan motif-motifnya yang indah dan sarat makna begitu unik, merepresentasikan budaya masyarakat Sumba yang istimewa. Bagi orang Sumba, tenun bukanlah sekadar kain, tetapi sesuatu yang sangat penting. Kain memegang peranan di dalam menyambut kelahiran, merayakan pernikahan, atau mengantarkan jenazah orang yang telah meninggal mengawali perjalanannya menuju keabadian. Kain-kain indah dengan lukisan-lukisan ditenunkan ke dalam rajutannya melalui teknik ikat. Itulah kain yang sering dipakai untuk melambari jenazah. Kain-kain ini semua diisi dengan doadoa yang dipanjatkan oleh pembuatnya. Doa disematkan untuk masing-masing peristiwa penting di dalam kehidupan orang yang kelak memakai kainnya itu. Tenun ikat Sumba adalah salah satu bentuk dari kekayaan budaya yang dimiliki oleh Provinsi NTT. Tenun ikat Sumba merupakan kain nusantara nan eksotis yang diciptakan oleh para seniman tenun dari Sumba. Tenun ikat Sumba bukanlah kain yang bisa dikerjakan oleh sembarang orang.

Masyarakat penduduk Pulau Sumba, Nusa Tenggara Timur, mengandalkan hidup terutama dari kegiatan bertani atau beternak. Namun, menenun kain adalah mata pencaharian lain yang tak kalah penting. Kegiatan membuat kain ikat sudah menyatu dengan kesibukan keseharian masyarakat Sumba, khususnya kaum perempuannya. Sehari-hari, para ibu Sumba umumnya melakukan kegiatan menenun kain di sela-sela kesibukan mengurus rumah tangga dan 
membantu suami bekerja di ladang. Di Sumba, kebudayaan yang terkait dengan kain tenun ikat telah dikenal sejak ratusan atau bahkan mungkin lebih dari seribu tahun. Secara umum, di sana ada dua jenis pengrajin kain tenun. Pertama, pengrajin yang sepenuhnya menggantungkan hidup sepenuhnya dari kegiatan tersebut; kedua, mereka yang melakukan kegiatan menenun kain sebagai pekerjaan sambilan. Pengrajin atau seniman tenun sambilan umumnya adalah mereka yang secara sosial memiliki fungsi adat dalam masyarakat Sumba, seperti kaum bangsawan (maramba). Walaupun merupakan hasil kerja sambilan, kain tenun buatan kaum bangsawan Sumba ini umumnya bermutu tinggi karena kain yang mereka buat sesungguhnya bukan barang dagangan. Kaum maramba menenun kain hanya hanya utk disimpan sebagian dan hanya digunakan untuk memenuhi keperluan berbagai upacara adat.

Tenun ikat Sumba merupakan bagian dari kebudayaaan batu besar (kebudayaan megalitikum), kebudayaan zaman prasejarah yang masih memiliki banyak pendukung di Sumba. Eksistensi kebudayaan megalitikum masih dapat dilihat dalam upacara pemakaman kaum bangsawanya. Dalam upacara semacam itu, ratusan lembar kain tenun ikat dipakai sebagi penutup jenazah yang akan dimakamkan di bawah kubur batu berukuran besar.Secara tradisional, kain tenun ikat Sumba dibuat menggunakan zat-zat pewarna alami. Proses pembuatan selembar kain tenun ikat relatif rumit dan memakan waktu cukup lama. Proses pewarnaannya saja bisa memakan waktu berbulan-bulan, bahkan tahunan. Selain berkaitan dengan kebiasaan turun temurun, lamanya waktu yang diperlukan juga disebabkan karena jenis-jenis tumbuhan yang menjadi sumber zat warna-warna tertentu hanya tumbuh pada musim-musim tertentu. Pada musim penghujan para penenun melakukan kegiatan mengikat benang, membentuk motif yang diinginkan, sekaligus menyiapkan bahan-bahan pewarna. Warna merah, misalnya, dihasilkan dari akar mengkudu yang dicampur daun loba. Proses pencelupan (pewarnaan) baru dimulai pada musim kemarau. Karena bergantung pada bahan-bahan alami, pilihan warnanyapun terbatas. Warna biru, merah hitam dan kuning, merupakan warna yang biasa digunakan. Proses pewarnaannya relatif rumit dan memerlukan kesabaran. Paling tidak diperlukan empat kali pemrosesan untuk mendapat satu warna yang diinginkan. Setelah proses pewarnaan selesai, ikatan-ikatan dibuka, benang diurai, sebelum proses penenunan dimulai.

Seiring perkembangan zaman, kain tenun ikat Sumba pun bekembang pada berbagai aspeknya. Sudah sejak beberapa puluh tahun lalu ia tak lagi hanya diproduksi untuk memenuhi kebutuhan busana dan upacara adat orang Sumba.

Kain tentun ikat Sumba juga dibuat untuk memenuhi permintaan pasar di luar Sumba yang terus tumbuh. Sebagain dibuat untuk para kolektor tekstil, sebagian lagi diproduksi secara lebih massal dan kasar sebagai cendera mata bagi para para wisatawan yang datang ke Sumba atau Bali, tempat dimana kain tenun ikat Sumba yang sudah sohor ke segala penjuru dunia ikut mengisi toko-toko cinderamatanya. Para pedagang dan pengrajin pun mencoba mengikuti selera pasar. Gambar dan ragam hias kain yang mereka produksi dipilih yang dianggap lebih gampang 'dijual'. Gambar tengkorak yang secara kultural menjadi kebanggaan orang Sumba lambat laun mulai menghilang dari kain tenun ikat Sumba karena, konon, wisatawan Jepang kurang menyukai gambar ini. Munculnya gambar manusia dalam ukuran besar di kain sumba juga merupakan hasil penyesuaian dengan selera pasar.

Kerajinan tenun ikat di Sumba Barat memiliki ragam motif dan corak tersendiri berdasarkan masing-masing wilayah. $\mathrm{Di}$ wilayah Wanokaka, Lamboya dan Tana Righu ada kain panggiling, pahikung dan pawora sementara di Loli terkenal dengan kain lambaleko. Jenis-jenis kain tersebut terkait dengan teknik pembuatan motif dan pewarnaannya. Pahikung adalah jenis kain yang dibuat dengan teknik ikat. Pawora dibentuk dengan teknik anyaman yang kemudian diberi pewarna alami (wora), sementara lambaleko dibuat menggunakan lidi atau bilah bambu yang disisipkan pada selasela benang lalu diungkit dan ditekan mengikuti pola-pola tertentu. Tidak seperti di Sumba Timur, motif kain tenun di wilayah Sumba Barat umumnya kecil-kecil dan sedikit abstrak. Pada kain laki-laki motif seringkali berupa garis, titik-titik, dan mamoli di tepinya. Sementara motif yang terdapat pada kain wanita aslinya berupa belah ketupat (mata kerbau) dan segi tiga (ekor kuda). Menurut Janet Hoskins motif-motif tersebut diadopsi dari benda-benda yang diberi pihak laki-laki 
sewaktu meminang seorang gadis (belis). Sementara benda-benda yang diberikan pihak perempuan seperti babi atau gading dianggap tabu. Mamoli yang merefliksakan seksualitas wanita digambar pada kain laki-laki, sementara mata kerbau dan ekor kuda yang merupakan simbol-simbol maskulin di gambar pada kain perempuan. Pada acara-acara adat kedua kain ini selalu hadir berpasangan sebagai gambaran transaksi yang seimbang.

Dewasa ini motif kain tenun tidak lagi mengikuti pakem tradisional. Misalnya mamoli, kini banyak muncul pada kain perempuan, ada pula motif kepiting yang merupakan simbol kebangsawanan. Bahkan motif paling baru berupa burung di kolam air mancur yang banyak muncul belakangan ini tidak memiliki makna apa pun, sekedar hiasan dekoratif yang dicontoh sang penenun dari buku-buku bergambar. Namun hal-hal yang dianggap tabu tetap tak berubah, hingga hari ini tidak pernah ada yang mengaplikasikan belis balasan pihak wanita sebagai motif kain tenun. Selain memenuhi fungsi praktis sebagai bahan pakaian, kain tenun tradisional Sumba Barat juga memiliki makna sosio-religius. Kain tenun dapat mendongkrak prestise sosial seseorang. Makin banyak jumlah kain yang dimiliki, makin beragam corak dan warnanya, makin tinggi pula kedudukan pemiliknya di mata masyarakat. Motif tenunan biasanya bergambar Bintang, Kuda, Mamoli, Belah Ketupat, Mata kerbau, Ayam, dan Kupu kupu.

Alat tenun tradisional biasanya terbuat dari Kayu dan bambo, nama alatnya yaitu:

- B'edo (penahan tulang belakang yang mengencangkan tenunan)

- Beibmaba (untuk mengatur kelonggaran kain)

- Klooro b'endo (untuk menghubungkan antara b'edo dan beibmaba)

- Kwehek (untuk menahan kain yang telah di tenun)

- Hab'elung (untuk menggulung benang yang dimasukan dalam kain lalu dirapikan oleh malira)

-Wunongo (untuk membuat motif - motif dalam kain)

- Ombol (untuk mengisi benang yang di tenun)

- Rad'a (gandengan ombol sebagai penahan)

- Talanda (untuk tumpuan kaki)

- B'eijongu (penahan)

Profil wanita pengrajin tenun ikat di Kampung Prai ljing member gambaran bahwa Kampung Prai ljing adalah Kampung tradisional yang masih asli dengan pemandangan yang sangat cantik. Kampung ini terletak di atas sebuah bukit kecil berlevel
3. Dari level paling atas atau yang kedua kita bisa melihat keseluruhan kampung yang terhampar di level paling bawah, amat mempesona.Waktu terbaik untuk berkunjung adalah di pagi hari saat warga mulai beraktifitas atau di sore hari saat mereka kembali dari sawah dan ladang. Berlokasi di Kecamatan Kota Waikabubak, dengan jarak 3 $\mathrm{km}$ dari pusat kota. Kondisi jalan menuju kampung berupa jalan aspal dengan kondisi baik. Kondisi jalan di dalam kampung berupa jalan tanah dengan kondisi cukup baik. Moda transportasi umum yang tersedia tidak sampai ke kampung sehingga wisatawan lebih memilih jasa rentcar.

Kampung Prai ljing merupakan kampung Tenun lkat yang diproduksi oleh para pengrajin di Desa Tebar, Kecamatan Kota, Kabupaten Sumba Barat. Jika dicermati didalamnya mengandung nilai-nilai yang pada gilirannya dapat dijadikan sebagai acuan dalam kehidupan sehari-hari bagi masyarakat pecinta pecinta Tenun Ikat. Nilai-nilai itu antara lain, kesakralan, keindahan/seni, ketekunan, ketelitian dan kesabaran. Nilai keindahan tercermin dari motif ragam hiasnya yang dibuat sedemikian rupa sehingga memancarkan keindahan, sedangkan nilai ketekunan, ketelitian dan kesabaran tercermin dari proses pembuatannya yang cukup menyita waktu yang panjang dan lama untuk menghasilkan sebuah Tenun lkat yang bagus, menarik, dan disukai oleh banyak orang. Tenaga kerja pada usaha kerajinan Tenun Ikat adalah tenaga wanita berasal dari anggota rumah tangga sendiri dan sebagian lagi mengupah pekerja dari tetangga di dekat rumah. Suami mereka bekerja sebagai petani atau pekerjaan lain diluar pertanian. Pekerjaan menjadi pengrajin Tenun lebih banyak ditekuni oleh wanita karena menenun memerlukan ketelitian, keuletan, dan ketekunan yang tinggi, dan wanita yang memang cocok melakukan pekerjaan itu.Tenaga kerja laki-laki biasanya hanya membantu saja terutama dalam hal pemasaran.Kegiatan kerajinan Tenun Ikat memerlukan keahlian khusus, sehingga tidak mudah bagi setiap orang untuk terjun ke dalam usaha tersebut.Kerajinan Tenun Ikat di desa ini merupakan kerajinan yang diwariskan secara turun temurun diperoleh dari orang tua, sehingga pada umumnya kerajinan Tenun Ikat masih dikerjakan untuk meneruskan usaha orang tua.

Kemampuan pengusaha lokal dalam mengelola usaha perekonomian terutama dalam industri kerajinan tenun Sumba Barat mendapatkan perhatian dari pemerintah melalui pemerintah Kabupaten Sumba. Beberapa kegiatan yang dilakukan pemerintah 
seperti pemberian pelatihan mengenai tenun ikat melalui dinas koperasi dan perdagangan. Dukungan lain dengan pemberian bantuan usaha dari Bank kepada para usaha tenun di Sumba Barat. Bantuan dana usaha yang diberikan untuk daerah di Kabupaten Sumba Barat masih terbatas dananya .Untuk itu kain yang dihasilkan tidak terlalu banyak mengingat sanggar -sanggar penenun adalah masyarakat ekonomi menengah ke bawah. Biasanya anggota dari sanggar-sanggar penenun membayar iuran untuk membeli bahan-bahan untuk membuat kain yaitu; benang dan zat pewarna benang. Untuk alatalat pembuatan kain tenun, kebanyakan alatalat untuk menenun masih masih sangat sederhana yang dibuat dari kayu.

Ditinjau dari bahan dan proses pembuatannya dari dulu penenun Sumba Barat, menenun memakai kapas yang tumbuh di lingkungan alam mereka dan dapat dipintal menjadi benang. Untuk bahan pewarna kain mereka juga mengambil di lingkungan hidup mereka. Dahulu untuk membuat kain bahan pewarna alam yang dipakai adalah berasal dari tumbuh tumbuhan seperti pohon phonan seperti mengkudu dan tanaman liar. Untuk sekarang, penenun kurang menenun dengan memakai benang yang terbuat dari kapas karena hasil tenunan lama, mutu kain agak berat dan kurang diminati oleh pembeli lokal mereka lebih suka memakai benang pabrik dan bahan pewarna kain atau disebuat wanteks.

pada umumnya perempuan. Biasanya penenun menenun pada waktu siang sesudah habis kegiatan rumah tangga seperti masak, mencuci pakaian dan lain-lain. Menurut mereka, untuk menenun sebuah kain yang dilakukan sesudah habis mengurus rumah tangga biasanya dikerjakan selama kurang lebih 1 bulan. sedangkan kalau menenun tanpa mengerjakan pekerjaan rumah tangga yaitu memasak, mencuci dan lain-lain, pekerjaan ini dimulai dari pagi sampai sore hari dikerjakan selama 2 minggu. Pada umumnya di Sumba Barat seorang penenun mulai dari awal pembuatan motif kain sampai selesai membuat sebuah kain tenun bisa dikerjakan sendiri.Di Sumba Barat sanggarsanggar tenun membuat kain tenun dengan dua cara yaitu dengan membuat kain tenun dari bahan kapas yang dipintal menjadi benang dan membeli benang dari toko, menurut mereka kain tenun dari bahan kapas banyak digunakan untuk acara-acara adat dan juga banyak dicari/dibeli oleh turis-turis dari mancanegara karena harganya lebih mahal.

Menurut turis yang membeli kain tenun dari bahan kapas mengatakan bahwa kain tenun lebih unik dan dianggap sebagai barang antik dengan warna-warni kain yang dibuat dari zat pewarna alamiah. Pertamatama untuk membuat sebuah kain tenun terlebih dahulu harus dibuat motif pada sehelai kertas, sebelum pembuatan motif yang akan diikat pada benang untuk ditenun. Sesudah itu benang yang akan dipakai warnanya sesuai dengan selera penenun. Ada sanggar-sanggar yang masih menenun memakai benang yang dipintal dari kapas dan memakai benang yang dibeli dari toko, tetapi ada sanggar-sanggar yang tidak lagi memakai benang yang dipintal dari kapas, tetapi hanya membeli benang yang sudah jadi di toko.

Disini akan diuraikan cara pembuatan kain tenun dari bahan benang kapas dan dari bahan benang pabrik.

\section{a. Kain Tenun dari benang kapas}

Untuk pembuatan kain tenun yang bermotif klasik mereka membuatnya dari bahan kapas. Yaitu mula-mula kapas dibersihkan dari bijinya dengan cara memakai alat yang disebut busur/huskwe (bahasa Selaru), sesudah itu kapas yang sudah bersih dimasukan ke dalam tempat yang disebut sulbeli atau bakul kecil yang dianyam dari daun koli. Untuk memintal kapas menjadi benang yang disebut sule, terbuat dari kayu atau bambu dengan garis tengah kurang lebih $4 \mathrm{~mm}$, dan panjang sekitar $20-25 \mathrm{~cm}$ dengan bagian bawahnya dipasang kayu bulat tipis yang garis tengahnya kurang lebih $3 \mathrm{~cm}$, juga digunakan alat bantu berupa kapur atau abu untuk melicinkan jari tangan.Benang yang telah dipintal kemudian dipindahkan ke kokobal ain untuk memudahkan penenun menghitung jumlah benang yang dibutuhkan dalam menyelesaikan sebuah tenunan. Sesudah itu benang dililit pada batu kerikil menjadi bola-bola kecil. Benang yang sudah dililit menjadi bola-bola kecil di letakkan pada snyarwain/ nyiru untuk nantinya dijalankan pada ngenget ain pada saat mau mengikat bunga. Selanjutnya benang dipasang pada ngenget ain dengan tujuan untuk mengikat motif/bunga sekaligus juga sebagai alat untuk menentukan lebarnya kain yang akan 
ditenun. Benang yang telah dipasang pada ngenget ain kemudian di bagi menjadi beberapa kelompok, selanjutnya setiap kelompok di ikat pada bagian-bagian tertentu untuk mendapatkan motif yang ingin digambarkan, selain itu pengikat juga berfungsi untuk melindungi motif dari warna yang tidak diinginkan pada saat pencelupan.

Untuk memudahkan seorang penenun mengikat keseluruhan rencana ornament/motif, mereka harus menggambarkannya terlebih dahulu. Gambar tersebut dijadikan dasar bagi sang penenun untuk melakukan ikatan. Untuk membedakan setiap ikatan untuk motif/ragamhias dibuat tanda khusus pada ujung daun koli antara lain ikatan 1, ikatan 2, ikatan 3 dan seterusnya. Setelah ditemukan tali rafia tali dari daun koli ditinggalkan orang. Tali rafia dirasa lebih baik karena memiliki beberapa warna yang dapat membedakan disain motif/ragam hias. Benang yang telah diikat kemudian di beri warna dengan cara dicelupkan ke dalam panci yang telah berisi bahan pewarna. Untuk bahan pewarna kain mereka mengambil di lingkungan mereka.

Waktu dulu orang Sumba Barat membuat kain menggunkan pewarna alam. Untuk pembuatan benang berwarna hitam dengan cara daun diremas-remas dan dimasukan ke dalam air, sesudah itu benang dimasukan dan direndam kurang lebih selama 2 jam, sesudah itu dianggkat dan digantung dan dijemur di panas matahari sampai kering. Sesudah benang dijemur kering, maka proses selanjutnya adalah benang dilepas dan diatur pada alat tenun untuk siap ditenun.

\section{b. Kain Tenun Dari Benang Pabrik}

Untuk pembuatan kain tenun dari benang pabrik hampir semuanya sama dengan proses pembuatan kain tenun dari benang kapas. Perbedaannya yaitu pada saat pembuatan kain tenun dari kapas harus dipintal lebih dahulu menjadi benang sesudah itu baru di buat kain tenun, sedangkan untuk benang pabrik langsung diproses menjadi kain tenun. Untuk membuat kain tenun dari benang pabrik biasanya penenun sebelum menenun menjadi kain terlebih dahulu benang dicuci, sesudah kering baru ditenun tujuannya agar pada saat sudah menjadi kain tenun, mutu/kualitas kain lebih baik.

Perbedaan lain dari benang yang dipintal dari kapas yaitu; saat sudah menjadi kain tenun lebih berat dari kain tenun yang dibuat dari benang pabrik.

Pemberdayaan masyarakat di perdesaan sangat berkaitan erat dengan kegiatan perekonomian, yang dilakukan oleh masyarakat desa atau proses pemberdayaan ekonomi rakyat, untuk meningkatkan taraf kehidupan mereka menjadi lebih baik. Sejak lama pemerintah melakukan upaya peningkatan taraf kehidupan rakyat melalui pemberdayaan ekonomi, hal ini seperti pendapat Mubyarto, yang menyatakan kegiatan seperti ini adalah kegiatan produksi bukan kegiatan konsumsi. Masyarakat digiring menjadi produsen dari bahan lokal dan kemampuannya sendiri untuk memenuhi permintaan (konsumen).

Upaya pemberdayaan yang dilakukan di Kecamatan Kota, Waikabubak merupakan wujud pengentasan kemiskinan. Dalam program bantuan modal usaha bagi kelompok pengrajin tenun ikat diharapkan dapat menjadi produsen dari bahan lokal, serta kerampilan atau kemampuannya untuk memenuhi permintaan. Program pemberdayan yang sudah berjalan, diharapkan dapat berkelanjutan, jika melalui suatu perencanaan yang tepat sesuai dengan permasalahan yang menjadi kendalanya. Pentingnya peningkatan kemampuan dan kepandaian masyarakat, agar mampu mengembangkan komunikasi dan solidaritas antar mereka dalam kelompok, dan luar kelompok, sehingga pada akhirnya secara kritis mereka mampu berdiskusi untuk memecahkan masalah yang mereka hadapi secara bersama pula. Pemberdayaan masyarakat juga terukur melalui jaminan pendapatan, pengembangan kemampuan pengrajin, serta akses usaha dan kesempatan kerja yang lebih luas (Sumarti dan Syaukat,2006).

Dalam Pemberdayaan masyarakat diperlukan Sumberdaya Manusia, Modal Fisik dan Modal Sosial. Ketrampilan tenun ikat, merupakan warisan sumberdaya pengetahuan yang mendukung kegiatan ekonomi keluarga pengrajin, baik secara subsisten maupun komersial. Pengrajin tenun ikat, memiliki potensi yakni dalam hal ketrampilan atau pengetahuan, dan modal produksi yang meliputi kesediaan bahan baku maupun tenaga kerja. Bahan baku dapat berupa hasil bumi maupun bahan olahan yang dapat diperoleh dari dalam komunitas maupun dari luar komunitas. Sumberdaya manusia meliputi kemampuan dan ketrampilan yang dimiliki oleh individu dalam melakukan aktivitas produksi baik barang dan jasa. Modal ini mengacu pada suatu sumberdaya yang tidak dihabiskan 
dalam proses produksi barang (Haviland,1993 dalam Sumarti).

Tenaga kerja merupakan faktor produksi insani yang secara langsung maupun tidak langsung menjalankan kegiatan produksi. Faktor produksi tenaga kerja juga dikategorikan sebagai faktor produksi asli. Dalam faktor produksi tenaga kerja, terkandung unsur fisik, pikiran, serta kemampuan yang dimiliki oleh tenaga kerja. Oleh karena itu, tenaga kerja dapat dikelompokan berdasarkan kualitas (kemampuan dan keahlian) dan berdasarkan sifat kerjanya. Berdasarkan kualitasnya, tenaga kerja dapat dibagi menjadi tenaga kerja terdidik, tenaga kerja terampil, dan tenaga kerja tidak terdidik dan tidak terlatih. Ketrampilan pengrajin adalah sumber daya manusia yang dimiliki oleh hampir sebagian besar perempuan di Kecamatan Kota, Waikabubak sehingga menjadi potensi yang terus dikembangkan. Tenaga kerja merujuk pada jumlah warga yang terampil maupun belum terampil sebagai potensi sumberdaya manusia.

Modal fisik atau dalam ilmu ekonomi disebut faktor produksi fisik adalah semua kekayaan yang terdapat di alam semesta dan barang mentah lainnya yang dapat digunakan dalam proses produksi (Griffin R: 2006). Faktor yang termasuk di dalamnya adalah tanah, air, dan bahan mentah (raw material). Hal ini merujuk pada ketersediaan bahan baku alam di komunitas yang dapat dikembangkan untuk produksi. Modal sosial merupakan salah satu konsep baru yang diposisikan setara dengan modal alam dan modal ekonomi. Modal sosial didefinisikan sebagai informasi, kepercayaan dan norma-norma timbal balik yang melekat dalam suatu sistem jaringan sosial (Woolcock, 1998:153 dalam Nasdian dan Utomo, 2005

Penelitian ini menunjukkan bahwa adaptability IKM umumnya adalah sedang $(3,122-3,593)$ kemampuan industri kecil dalam adaptability usaha masih perlu ditingkatkan baik dalam melayani kebutuhan pelanggan, mengetahui strategi dari para pesaing maupun mengetahui informasi atau trend pasar yang diminati oleh para pelanggannya.Semangat kerja dari para pelaku usaha di Sumba Barat yang berorientasi kepada permintaan pasar (pelanggan), pesaing dan informasi pasar ini, hendaknya semakin ditingkatkan, peningkatan produktivitas kerja dari para pelaku usaha industri kecil kreatif di Sumba Barat, mutu (kualitas produk) lebih kreatif mengembangkan produk yang beradaptasi dengan permintaan pasar, sehingga sentra yang ada dapat lebih berkembang. Pasar yang dinamis, dengan jenis dan permintaan yang sangat fluktuatif, perlu diimbangi dengan strategi pemasaran yang kreatif dari para pelaku usaha.

Secara inovasi, kekhasan corak dan karakteristik dari industri tenun di Sumba Barat harus tetap dipertahankan, Adanya inovasi secara terus menerus supaya konsumen tidak mengalami kejenuhan, untuk itu perlu motivasi dari semua pihak yang terkait, baik pemerintah, dinas koperasi dan UKM dan dinas pariwisata. Adanya pola pikir dari para pengrajin secara berkesinambungan dalam meningkatkan kualitas prodak dan kombinasi saluran pemasaran serta melakukan promosipromosi melalui media massa maupun media elektronik.

Penelitian ini menunjukan persepsi responden menyatakan bahwa sikap pengusaha terhadap orientasi kewirausahaan seperti : pengalaman berusaha, proaktif, kemampuan mengambil risiko, flexibel, dan antisipatif. Diperlukan kualitas SDM yang baik dalam rangka pengembangan sentra UKM, didorong oleh keinginan kita untuk meningkatkan minat berwirausaha, motivasi berwirausaha, inisiatif dan proaktif, menyukai resioko, orientasi pada prestasi dan komitmen berbagai pihak. Pada sentra UKM yang terbentuk secara alamiah, lebih banyak dijumpai kualitas SDM yang belum optimal, sehingga upaya peningkatannya membutuhkan usaha ekstra.Kualitas SDM juga berimbas pada kemampuan wirausaha, baik sebagai ilmu, semangat, sikap maupun perilaku. Kemampuan, inisiatif, pengembangan rasionalitas bisnis, kemampuan mengelola konflik, dan membagi resiko, pada dasarnya akan bermuara pada kematangan dalam pengambilan keputusan secara menyeluruh. Perbaikan dalam faktor ini seringkali buntu karena perilaku kalkulatif yaitu, biaya yang dibutuhkan untuk meningkatkan kualitas SDM jauh lebih besar daripada tambahan kemanfaatan yang diperoleh. Daya Saing (Competitive Advantage)

Dari penelitian yang dilakukan, ditemukan bahwa salah satu faktor yang menjadi pendukung dari upaya pemberdayaan adalah komitmen pemerintah dalam melakukan pemberdayaan terhadap masyarakat UMKM (Usaha Mikro Kecil dan 
Menengah) Tenun Ikat Sumba Barat. Pemerintah memberikan fasilitas dalam mendukung produk tenun ikat agar mempunyai arti dimata masyarakat dan terus berkembang. Produk tenun ikat merupakan harta yang dimiliki Sumba Barat. Salah satu bentuk dukungannya yaitu melalui kegiatan pameran produk tenun ikat. Selain dukungan dari pemerintah daerah , masyarakat khususnya masyarakat penenun pada tenun ikat. Masyarakat memiliki antusias dalam mempertahankan dan memajukan kerajinan Tenun Ikat. Dengan adanya keinginan dari masyarakat itu sendiri untuk berkembang maka dapat memperlancar upaya pemberdayaan.

Ada beberapa hal pula yang menjadi faktor penghambat pemberdayaan masyarakat penenun di Kecamatan Kota, Sumba Barat yaitu , masih kurangnya kegiatan pendidikan dan pelatihan yang dikhususkan untuk para penenun atau masyarakat pengrajin Tenun Ikat. Bantuan pinjaman modal dari pemerintah juga belum mampu membangkitkan antusiasme para pelaku usaha kerajinan Tenun ikat untuk mengaksesnya, sulitnya mendapatkan bahan baku dengan cepat juga menjadi faktor penghambat dari upaya pemberdayaan. Tidak semua penenun atau pemilik usaha kerajinan yang mampu berkembang dan bertahan seiring dengan perubahan zaman.

\section{PENUTUP}

Pengaruh budaya, adat istiadat dan pandangan hidup terhadap bentuk dan wujud kain tenun yang dihasilkan atau yang dikembangkan oleh setiap suku bangsa yang memiliki karakter, gaya tersendiri, ciri terutama bentuk, ragamhias/motif dan warna yang digunakan. Hal ini selalu berkaitan erat dengan latar belakang geografis sejarah dan budaya. Oleh sebab itu kain tenun bukan saja untuk busana dan lain-lain melainkan juga karya suatu kebudayaan.

Sumba Barat merupakan salah satu suku, secara geografis terletak di pulau Sumba. Budaya menenun bagi masyarakat Sumba Barat mengalami perkembangan dari masa kemasa, dengan tidak meninggalkan arti dan makna yang terkandung didalamnya. Nilai-nilai dalam motif kain tenun tersebut melekat dan terus dipertahankan oleh masyarakat karena dianggap sebagai ungkapan jati diri mereka. Karya-karya indah para leluhur mereka terus dipertahankan dalam melakukan aktivitas hidup. Hal ini dapat terlihat dalam penggunaan kain tenun dalam busana adat (pelantikan raja, upacara penghormatan jenasah, upacara kematian) pakaian pengantin serta pakaian kerja bagi PNS dan untuk baju rompi bagi anak-anak sekolah SD, SMP dan SMU/SMK.

Kain tenun dengan berbagai bentuk ragam hiasnya adalah merupakan usaha pengrajin tradisional yang didalamnya terdapat usaha untuk melestarikan budaya daerah dalam rangka pembinaan dan pengembangan kebudayaan nasional. Untuk itu kain tenun masyarakat Sumba Barat perlu mendapat perhatian dari pemerintah untuk bisa menambah biaya usaha pengrajin.

\section{DAFTAR PUSTAKA}

Ali, Jakup., dkk. (1991) Tenun Tradisional Nusa Tenggara Barat, Proyek Pengembangan Permuseuman Nusa Tenggara Barat, Direktorat Jenderal Kebudayaan, Departemen Pendidikan dan Kebudayaan

Departemen Pendidikan dan Kebudayaan, (1992) Proyek Penelitian, Pengkajian, dan Pembinaan Nilai Budaya, Pengrajin Tradisional Daerah Nusa Tenggara Barat, Mataram.

Direktorat Sejarah dan Nilai Tradisional, (1992), Proyek Penelitian Pengkajian dan Pembinaan Nilai-Nilai Budaya, Direktorat Jenderal Kebudayaan, Departemen Pendidikan dan Kebudayaan.

Meoko, Norman., (2005) "Tasbih Kayu Cendana Asal Kupang Tembus Timur Tengah", Harian Sinar Harapan.

Profil Daerah Kabupaten dan Kota Jilid 1 (2001), Jakarta: Buku Kompas, Desember.

Profil Daerah Kabupaten dan Kota Jilid 4 (2004), Jakarta: Buku Kompas, April

Sarong, Frans, "Sasando, antara Pelestarian Budaya dan Peluang Usaha", Harian Kompas, Jakarta: PT. Gramedia, 2005.

Satuan Kerja Pemberdayaan Industri Kecil dan Menengah (PIKM), (2005) Company Profile Tenun Nusa Tenggara Barat, Mataram: Dinas Perindustrian dan Perdagangan Propinsi Nusa Tenggara Barat,.

Soemarsono (Penyunting), Perajin Tradisional di Daerah Propinsi Daerah Istimewa Yogyakarta, Jakarta: 
Staley, Eugene dan Rishard, Morse, (1965), Modern Small Industri for Developing Countries, New York: Mc. Graw Hill

Suhandi Shm., A., dkk., (1985) Pola Kehidupan Pengrajin Anyaman di Tasikmalaya, Jakarta: Proyek Penelitian dan Pengkajian Kebudayaan Nusantara (Javanologi), Direktorat Jenderal Kebudayaan, Departemen Pendidikan dan Kebudayaan

Tim Penyusun Kamus Pusat Pembinaan dan Pengembangan Bahasa (1990), Kamus Besar Bahasa Indonesia, Jakarta: Balai Pustaka, Cetakan ketiga.

Wiastuti, Alit dan Joko Prayitno, 1984, Gerabah Banyumulek Koleksi Museum Negeri Nusa Tenggara Barat, Mataram: Museum Negeri Nusa Tenggara Barat, Direktorat Jenderal Kebudayaan, Departemen Pendidikan dan Kebudayaan Nusa Tenggara Barat 